\title{
EVALUATION OF STRUCTURAL RELIABILITY USING SIMULATION METHODS
}

\author{
Markel BABALLËKU \\ Brisid ISUFI
}

\section{INTRODUCTION}

Reliability is defined in EN 1990 (Eurocode 0 - Basis of structural design, [1]) as "the ability of a structure or a structural member to fulfill the specified requirements, including the design working life, for which it has been designed". Reliability is usually expressed in probabilistic terms and it covers safety, serviceability and durability of a structure (see [1]). The following relation between the "probability of failure" $P_{f}$ and the index of reliability $\beta$ is given in EN 1990, Annex C:

$$
P_{f}=\Phi(-\beta)
$$

where $\Phi$ is the cumulative distribution function of the standardized Normal distribution. The probability of failure can be expressed through a performance function $g$ (also referred to as "limit state function", see [5], [6]) such that a structure is considered to survive if $g>0$ and to fail if $g \leq 0$. According to EN 1990, $P_{f}$ and $\beta$ are only notional values that do not necessarily represent the actual failure rates. They are used as operational values for code calibration purposes and comparison of reliability levels of structures. For structural elements of Reliability Class RC2 (as defined in EN 1990, Annex B), for the ultimate limit state, the recommended value of $\beta$ is 3.8 .

In general, a limit state function " $g$ " as defined above can be formulated for a given structure or structural member, but the probability of this function being smaller than zero or equal to zero, i.e. the probability of failure, is not always easy to be assessed. This is mainly due to the fact that the limit state function in general contains a large number of variables, with different probability distribution functions. Exact analytical integration, numerical

Markel Baballëku, Polytechnic University of Tirana, Faculty of Civil Engineering, Tirana, Albania, b kela@yahoo.com Brisid Isufi, Polytechnic University of Tirana, Faculty of Civil Engineering, Tirana, Albania, brisidi@yahoo.com integration, approximate analytical methods and simulation methods are among the most used methods of solving the probability of structural failure. Analytical integration and approximate analytical methods such as First Order Reliability Method (FORM) are limited to simple models. Numerical integration can handle more complex models, but however, the application is limited. Simulation methods have been developed lately along with the development of computers and practically, they can lead to solution for very complex models.

Simulation methods are used in this paper for the reliability analysis of a reinforced concrete bridge pier. Using computer simulations has an important advantage among the other methods; it allows a large number of variables into analysis. The limit state function " $g$ " can contain several geometric variables (such as length of elements, dimensions of cross sections, rebar diameters etc.), resistance variables (concrete strength, steel yield strength etc.) and action variables (self-weight of materials, environmental actions and imposed loads). Assessing the probability of a function " $g$ " with many independent variables being equal to or smaller than zero would be almost impossible without simulations.

A Monte Carlo simulation is a mathematical technique that involves a (usually) large number of iterations with different random values of inputs, each of which produces a different outcome. Monte Carlo simulations make it possible to study very complex problems and they suit the needs of reliability analysis of structures. Reliability design concepts and techniques are explained further in [5], [6] and [7].

\section{RELIABILITY ANALYSIS}

\subsection{Description of the bridge pier}

The transversal section of the bridge is shown in Figure 1. The bridge has several piers in a distance of $20 \mathrm{~m}$ (span length). For the analysis of the pier, the simplified cantilever model shown in Figure 1 was used, with $H=8 m$ and concentrated mass " $m$ ". 
The study is focused on the seismic design situation. The loads acting on the bridge pier are the axial forces from self-weight and traffic $(N)$, bending moment $(M)$ from eccentricity of traffic loads and the seismic forces. The pier is considered to be adequately fixed at basement. Geotechnical aspects are not considered further in this paper for the reliability analysis of the pier.

The cross section of the bridge pier shown in Figure 1 has nominal dimensions $h=3.4 \mathrm{~m}, b=2.2 \mathrm{~m}$ and $R=1.1 \mathrm{~m}$. The ground type according to Eurocode 8 (see [3]) is considered of Type A.

\subsection{Definition of variables}

When a structure is designed or when an existing structure is assessed, it is impossible to have perfect knowledge for all the factors that influence the results of calculations. Even for the simplest structures, several uncertainties exist. As it is shown in Figure 2, for the bridge pier, it cannot be sure if the cross section has the required dimensions, if reinforcement bars are placed perfectly correct, if their diameter is equal to the specified diameter or if the shape of the bars matches perfectly with the design. Also, it cannot be sure if concrete strength and yield strength of steel will be higher or lower than those specified. The same uncertainties apply to permanent actions, seismic and traffic loads and even the design model of the reinforced concrete section (e.g. the stress block dimensions).

The pier can be either a new one or an existing one. In the case of a new pier, the Probability Distribution Functions (PDFs) of the variables would represent the probable values. In case of existing bridges, if sufficient tests are available these PDFs will represent the actual distributions.

Recommendations from literature have been used in this paper for the distribution functions of the variables summarized in Table 1. For resistance and loads, the distributions have been chosen with mean value and coefficient of variation such that the characteristic fractile corresponds to a predefined value (see the comments column in Table 1). Model uncertainties have been introduced as multiplicative stochastic variables in the design equations (e.g. multiplying the other variables), with mean value equal to 1 . In Table $1(F)$ denotes actions, $(R)$ resistances and (a) geometry variables.
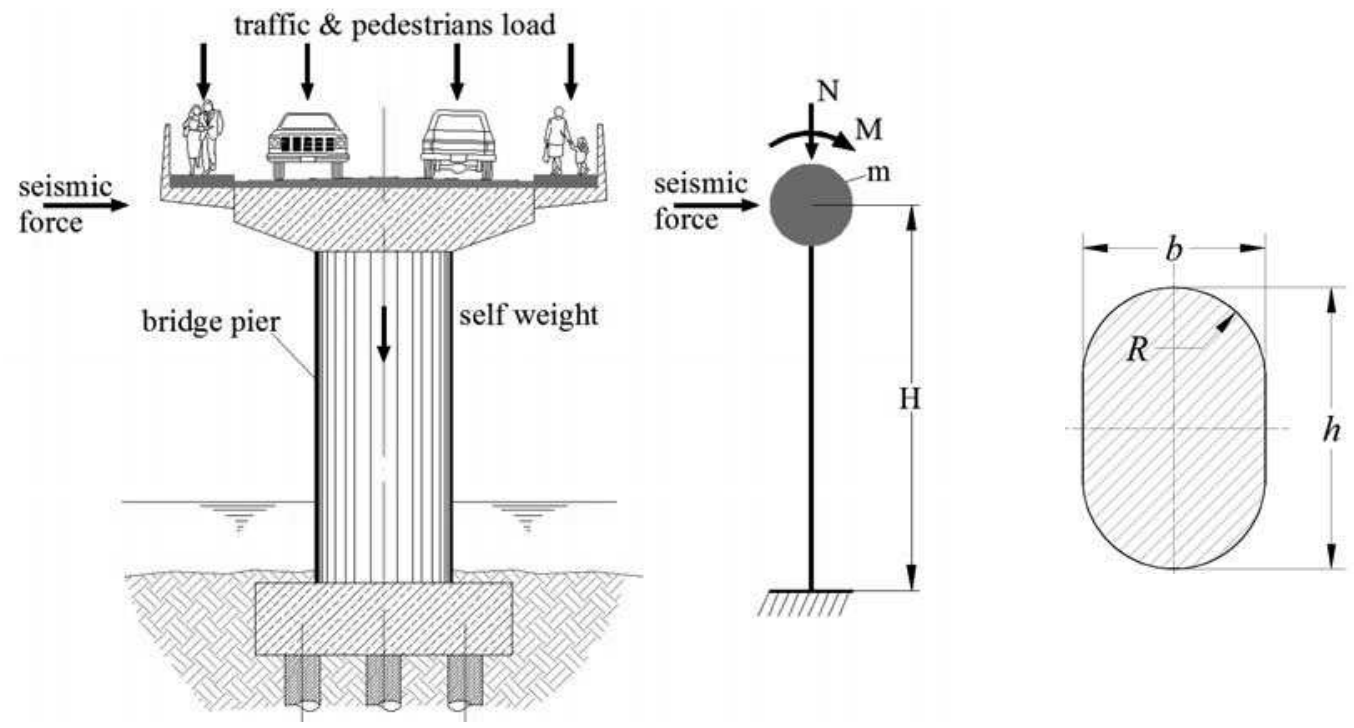

Figure 1. Section of the bridge showing the pier under analysis (left), structural model (middle) and cross section of pier (right)

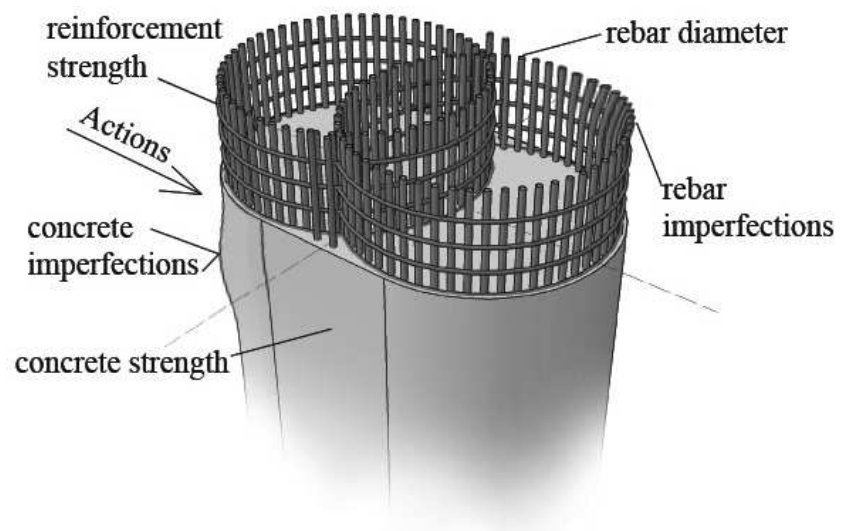

Figure 2. Some of the possible imperfections and uncertainties in the reinforced concrete pier 
Table 1. Definition of variables considered

\begin{tabular}{|c|c|c|c|c|c|c|}
\hline $\mathrm{Nr}$. & Variable & Distribution & Mean & $\begin{array}{l}\text { Coef. of } \\
\text { variation }\end{array}$ & Unit & Comment \\
\hline 1 & $\begin{array}{l}\text { Weight of reinforced } \\
\text { concrete }(F)\end{array}$ & Normal & 25 & $10 \%$ & $\mathrm{kN} / \mathrm{m}^{3}$ & Based on [9] \\
\hline 2 & Traffic loads $(F)$ & & & & & $\begin{array}{l}\text { LM1 with } 5 \% \text { probability of } \\
\text { exceedance in } 50 \text { years, } \\
\text { see [2], [4] }\end{array}$ \\
\hline 3 & Seismic action $(F)$ & & & & & $\begin{array}{l}a_{g}=0.25 \mathrm{~g} \text { with } 10 \% \\
\text { probability of exceedance } \\
\text { in } 50 \text { years, [3] }\end{array}$ \\
\hline 4 & $\begin{array}{l}\text { Concrete compression } \\
\text { strength }(R)\end{array}$ & LogNormal & 38 & $15 \%$ & $\mathrm{MPa}$ & $\begin{array}{l}\text { Characteristic value } 30 \mathrm{MPa} \\
(5 \% \text { fractile), [1], [5], based } \\
\text { on [9] }\end{array}$ \\
\hline 5 & $\begin{array}{l}\text { Reinforcement yield } \\
\text { strength }(R)\end{array}$ & LogNormal & 430 & $5 \%$ & $\mathrm{MPa}$ & $\begin{array}{l}\text { Characteristic value } \\
400 \mathrm{MPa}(5 \% \text { fractile), [1], } \\
{[5], \text { based on [9] }}\end{array}$ \\
\hline 6 & Model uncertainty & LogNormal & 1 & $5 \%$ & - & $\begin{array}{l}\text { Multiplicative variable, } \\
\text { based on [9] }\end{array}$ \\
\hline 7 & $\begin{array}{l}\text { Concrete modulus of } \\
\text { elasticity }(R)\end{array}$ & Normal & $3.4 \times 10^{7}$ & $1 \%$ & $\mathrm{kN} / \mathrm{m}^{2}$ & Assumption \\
\hline 8 & $\begin{array}{l}\text { Reinforcement modulus } \\
\text { of elasticity }(R)\end{array}$ & Normal & $2.0 \times 10^{8}$ & $0.6 \%$ & $\mathrm{kN} / \mathrm{m}^{2}$ & Assumption \\
\hline 9 & Height of the pier (a) & Normal & 8.0 & $0.06 \%$ & $\mathrm{~m}$ & Assumption \\
\hline 10 & Span length (a) & Normal & 17.0 & $0.06 \%$ & $\mathrm{~m}$ & Assumption \\
\hline 11 & Deck section area $(a)$ & Normal & 10.22 & $0.1 \%$ & $\mathrm{~m}^{2}$ & Assumption \\
\hline 12 & Height of pier section (a) & Normal & 3.4 & $0.06 \%$ & $\mathrm{~m}$ & Assumption \\
\hline 13 & Pier rebar diameter $(a)$ & Normal & 30 & $0.3 \%$ & $\mathrm{~mm}$ & Assumption \\
\hline 14 & Weight of road layers $(F)$ & Normal & 28 & $10 \%$ & $\mathrm{kN} / \mathrm{m}^{3}$ & Assumption, based on [9] \\
\hline
\end{tabular}

The seismic hazard for the bridge pier is represented by a reference ground acceleration $a_{g R}=0.25 \mathrm{~g}$ with a probability of exceedance equal to $10 \%$ in 50 years. Assuming that the maximum ground acceleration is inaccurately known, a random ground acceleration (larger than $0.25 \mathrm{~g}$ ) multiplied by a Bernoulli variable with mean value 0.1 (as shown in Figure 3 ) is assumed to represent the "strong" seismic event. For earthquakes with ground acceleration smaller than $0.25 \mathrm{~g}$, the bridge pier was analyzed separately.
Considering the seismic design situation, the probability of simultaneous occurrence of maximum values of seismic actions and traffic actions was assumed to be $1 \%$. Further studies are required for a more accurate assessment of the probability of simultaneous occurrence of these two actions.

The stress strain curves for concrete and steel were also considered stochastic, based on the distribution functions of concrete strength and steel yield strength. For a random value of concrete strength and yield strength of reinforcement, the stress strain curves are shown in Figure 4.

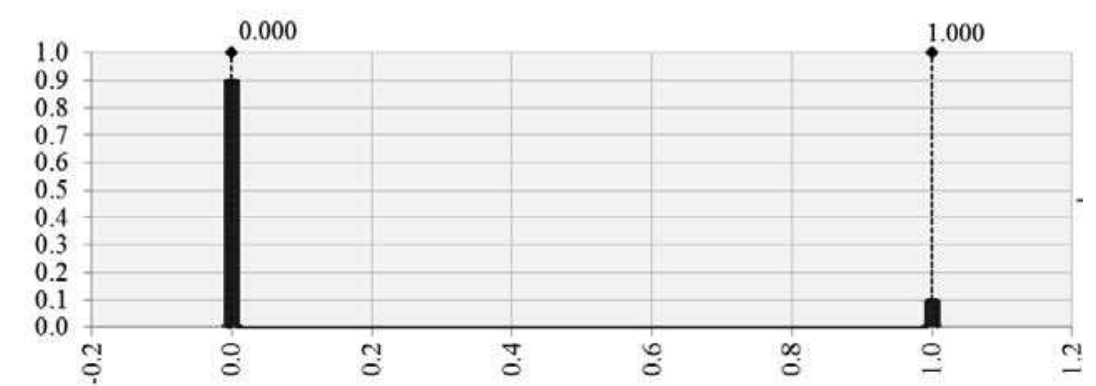

Figure 3. PDF of the multiplicative Bernoulli variable representing the "strong" seismic event 

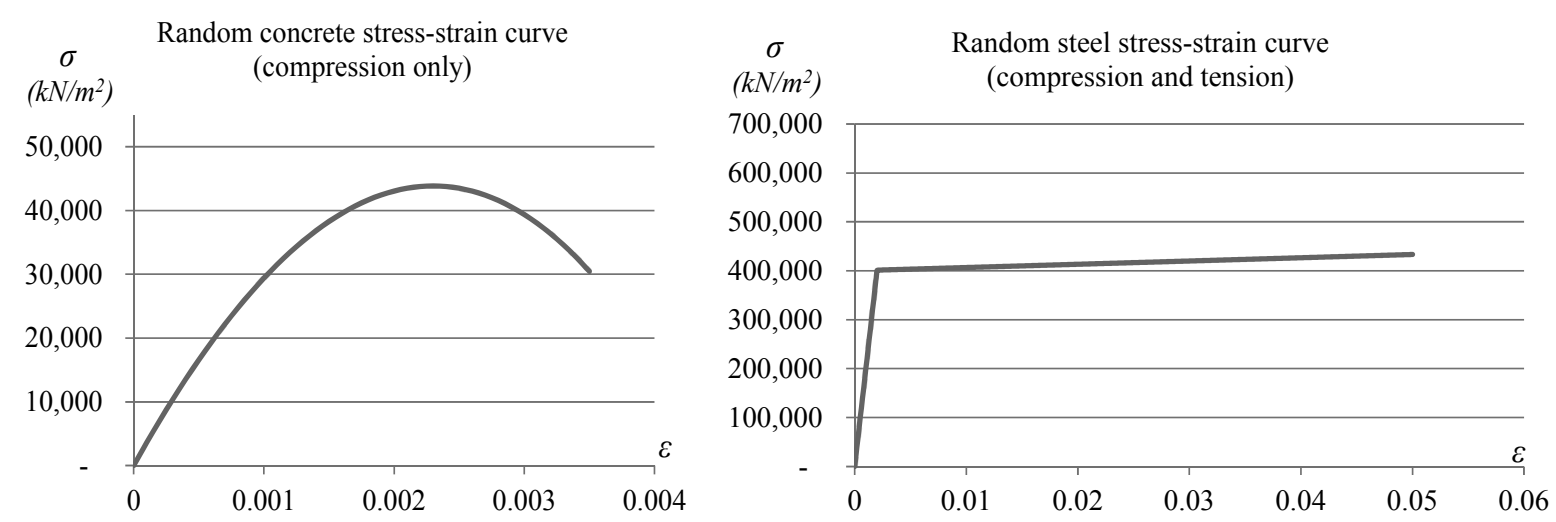

Figure 4. Stress strain curves of concrete and reinforcement for a random sample

In total 14 independent variables were considered for analysis. In general, more detailed and accurate distribution functions can enter the analysis if sufficient information is available (for example, from tests).

\subsection{Description of the procedure}

A worksheet in Microsoft Excel was built for the analysis of the pier. The basic idea is to run the procedure contained in the worksheet a large number of times while giving random values to the input variables and to collect and analyze the results. In other words, the random process of structural failure or survival has been modelled through a Monte Carlo simulation. In order to perform this simulation, specialized software Palisade @Risk was used. Figure 5 describes the whole procedure using a schematic algorithm.

After the definition of the input variables, the next step is "sampling". For each of the input variables defined in Table 1, samples are taken using the Monte Carlo method, then the internal forces and displacements are calculated through the worksheet and the results are stored in Microsoft Excel to be further processed. The procedure is repeated until a predefined number of iterations are performed.

The number of iterations performed in a simulation is important. The expected probability of failure is in the range of $1 \times 10^{-4}$ or less, because for an index of reliability $\beta=3.8$, the probability of failure will be:

$$
P_{f}=\Phi(-\beta)=\Phi(-3.8)=0.00007235
$$

In other words, if only 10,000 iterations were performed in a simulation, 0 or 1 failure event could have been observed, which means that the possible error is high. In order to reduce the uncertainty of the estimate of probability, several simulations were performed, with number of iterations per simulation ranging from 100,000 to $2,000,000$ until a satisfactory convergence was achieved. The estimated probability of failure at the end of the simulation is calculated as:

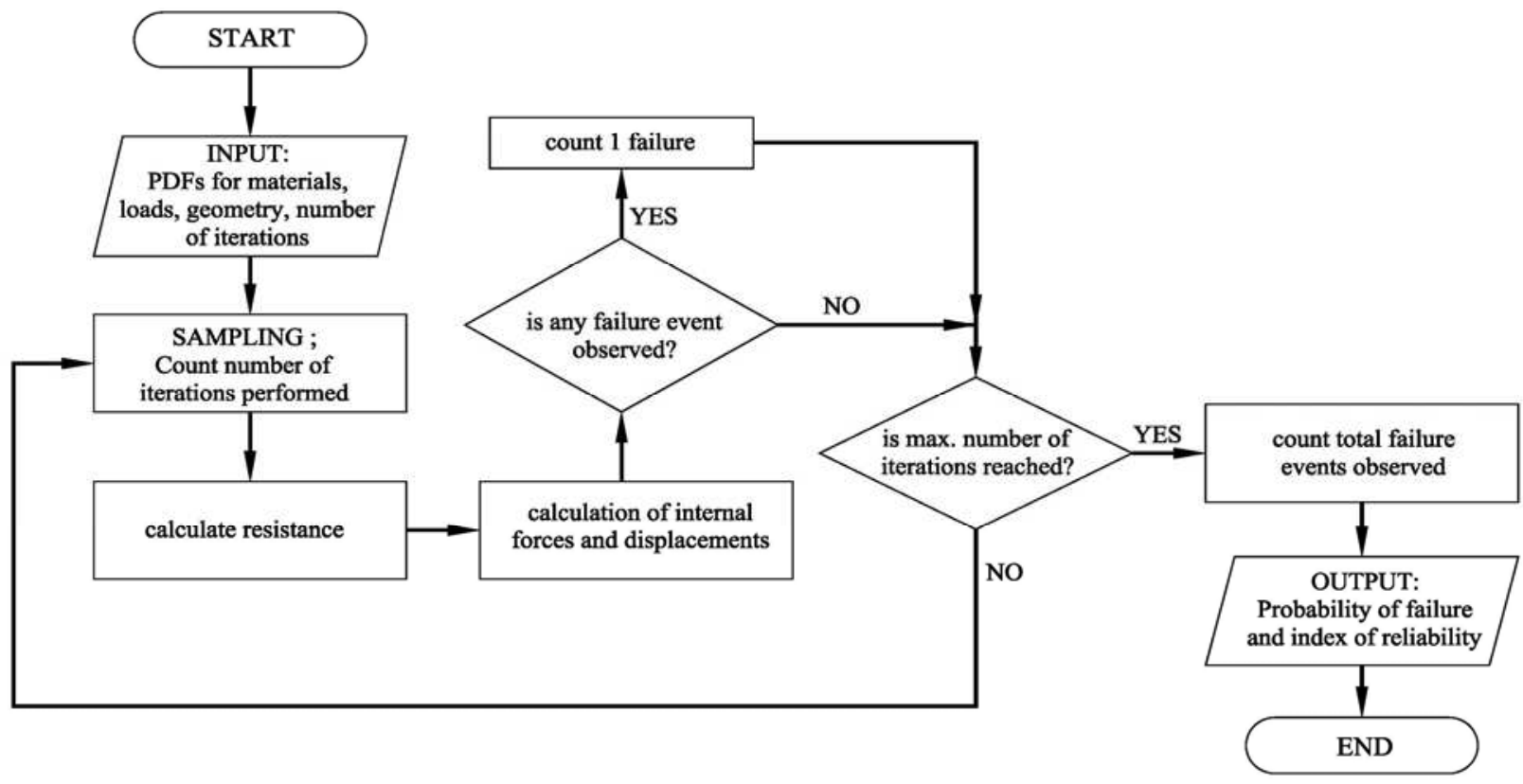

Figure 5. General algorithm for the estimation of index of reliability through Monte Carlo simulation 


$$
P_{f}=\frac{\text { number of failures observed }}{\text { number of iterations performed }}
$$

\subsection{Limit state function}

Rather than formulating a limit state function " $g$ " as the difference between the resistance and the action effects, a logical function that takes only values "1" and "0" was built (see the algorithm of Figure 5). If failure is observed, the function " $g$ " takes value " 1 ", otherwise its value is " 0 ". So, the distribution function of " $g$ " is a Bernoulli function with its mean value equal to the probability of encountering value " 1 ", i.e. equal to the probability of failure.

In order to calculate the resisting bending moment and axial force, the cross section was divided into layers as described in Penelis and Kappos [8]. For each iteration, the resisting axial force and the corresponding moment were calculated from the equilibrium of forces resulting from strain profile in Figure 6 , with the assumption that plane sections remain plane after deformation.

In Figure 6, $x$ is the depth of neutral axis and $\varepsilon$ denotes the strain of concrete (where index " $c$ " is used) or steel (with index "s") at any layer $i$. The following equilibrium equations shall apply when 20 layers are considered:

$$
\left\{\begin{array}{c}
N=\sum_{i=1}^{20} \sigma_{c i} A_{c i}+\sum_{i=1}^{20} \sigma_{s i} A_{s i} \\
M=\sum_{i=1}^{20} \sigma_{c i} A_{c i} y_{c i}+\sum_{i=1}^{20} \sigma_{s i} A_{s i} y_{s i}
\end{array}\right.
$$

The stresses $\sigma$ are calculated from the stress-strain diagrams presented in paragraph 2.2 for a given strain $\varepsilon$. Because of the shape of the pier and the reinforcement layout, the same number of layers was used for both concrete and steel. The equilibrium in (2.3) is fulfilled for a neutral axis depth $x$ which is calculated through iterations (see [8]).

Shear resistance of the pier was excluded in reliability analysis. Further studies can consider shear resistance and all the relevant failure modes, including geotechnical aspects.

Action effects are calculated based on Figure 7.

The seismic force is calculated through the elastic response spectrum for ground Type $A$ as the product of mass " $m$ " with the spectral acceleration calculated using Eurocode 8. The mass is calculated for each iteration of the simulation, and it takes into consideration the selfweight of the bridge superstructure and pier and the traffic loads (if present).

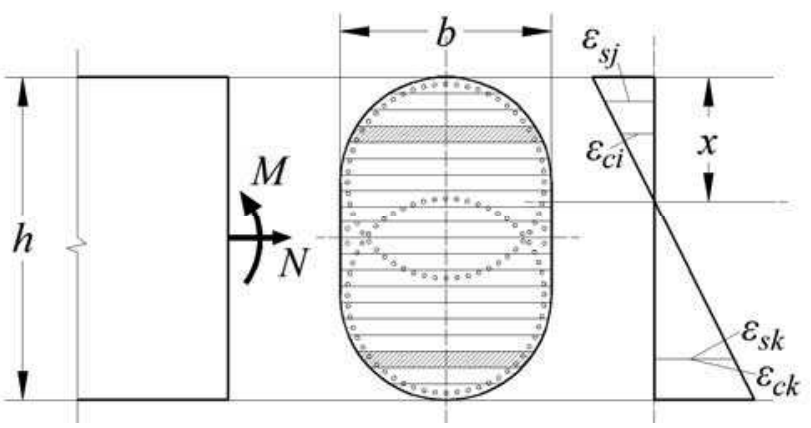

Figure 6. Cross section of the pier and the strain profile
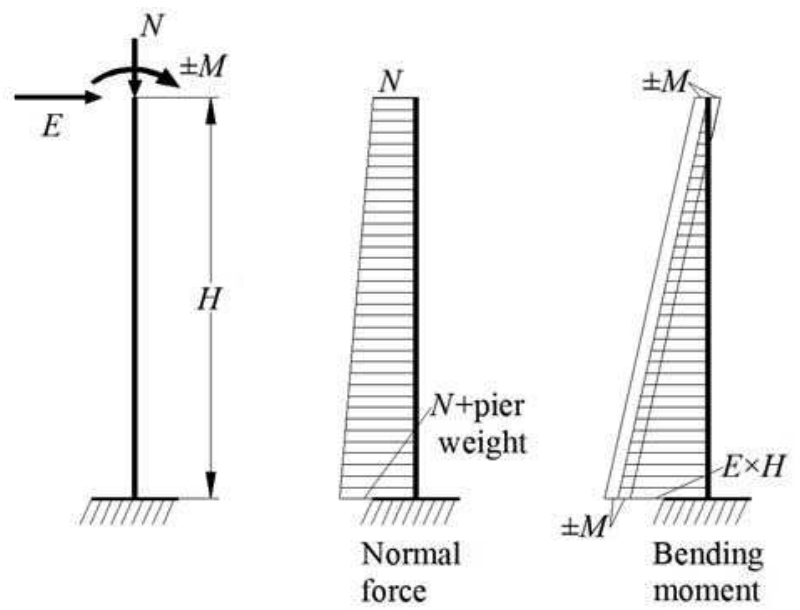

Figure 7. Normal force and bending moment in the bridge pier 


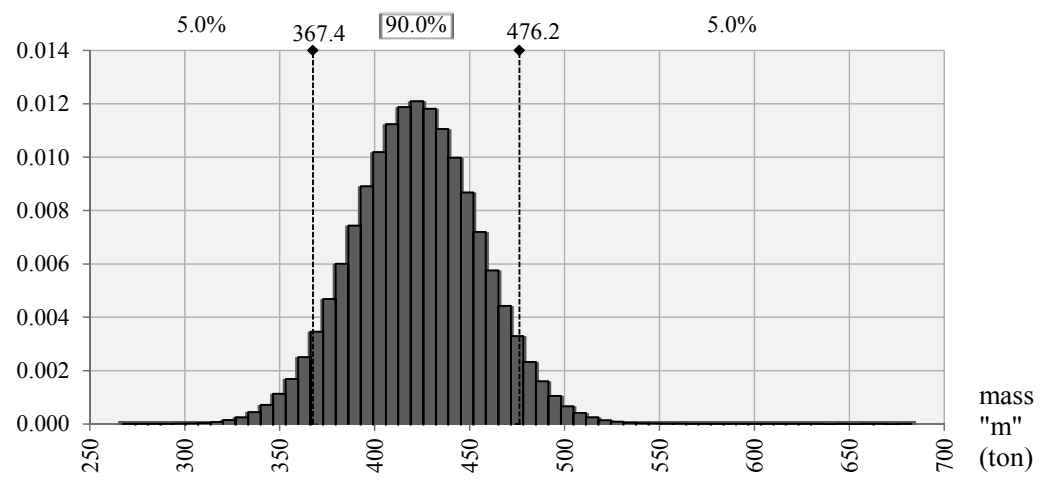

Figure 8. PDF of mass of the deck and pier in tons

Table 2. Estimated probability of failure for different number of iterations performed

\begin{tabular}{|l|r|r|r|r|}
\hline & \multicolumn{3}{|c|}{ Number of iterations in a simulation } \\
\hline Description & 100,000 & 500,000 & $1,000,000$ & $2,000,000$ \\
\hline Probability of failure of the pier & 0.0000100 & 0.0000110 & 0.0000200 & 0.0000205 \\
\hline Index of reliability $\beta$ & 4.26 & 4.24 & 4.11 & 4.10 \\
\hline
\end{tabular}

No partial factor or combination factor was included in the calculations presented above. The direct comparison of resistances with action effects described above leads to the result of $g=1$ or $g=0$ in an iteration. The procedure then follows the algorithm of Figure 5.

\section{RELIABILITY ANALYSIS RESULTS}

As described in paragraph 2.2, the ground acceleration during simulation exceeds $0.25 \mathrm{~g}$ in roughly $10 \%$ of iterations. Figure 8 shows the PDF of the concentrated mass "m" (see Figure 1). The variation of mass is due to geometrical variables, self-weight variables and the traffic variables. It is very important because it has direct influence on the fundamental period of the structure and the seismic force.

The analysis results are given in Table 2, for 100000 , 500000,1000000 and 2000000 iterations per simulation. The probability of failure and the accompanying index of reliability are calculated in the spreadsheet for each case and reported in the last row of the table.

Trial simulations with more than 2 million iterations showed that the probabilities estimated have insignificant differences. As a conclusion, based on Table 2, the bridge pier has a reliability level higher than the target value of " 3.8 ".

\section{COMPARISON WITH PARTIAL FACTOR METHOD OF EUROCODES}

The already created spreadsheet was used for the design of the reinforced concrete pier according to Partial Factor Method of Eurocodes, considering the seismic design situation. This time, the design values of the variables were used in the design equations, taken from the characteristic value, as defined in the Eurocodes, multiplied or divided by the relevant partial factors. The traffic loads LM1 were multiplied by the factor $\psi_{2,1}=0.2$ (see [1] to [5]).

In order to make the comparison possible, the design of the reinforced concrete pier according to Eurocodes using partial factors was done prior to the reliability analysis presented in the previous paragraphs. So, the area of reinforcement that resulted from the design according to Eurocodes is the same as the area of steel used for the reliability analysis. A design according to Eurocodes should lead to a reliability index larger than 3.8 (see [1]). The exact value of the index is "invisible" while designing using the partial factors.

On the other hand, the reliability analysis described in this paper leads to an estimation of the index of reliability. In our case, $\beta=4.1$.

\section{CONCLUSION}

Nowadays, computers offer a great tool for the structural engineer to solve complicated tasks. This paper presented in brief the procedure followed for the assessment of structural reliability of a reinforced concrete bridge pier. It was shown that simulation models can be implemented in calculation spreadsheet in order to solve complicated probability problems related to structural engineering. Given sufficient data is available, it is possible to actually design a structure or to assess its resistance and capacity based on the target reliability level. For the studied pier, the Eurocode Index of Reliability estimated through simulations resulted greater than the target index equal to 3.8. This means that, with the given input data, a more economical design could be possible. Especially for important structures such as bridges, simulation methods can lead to a realistic assessment of structural risk. The index of reliability gives a more clear idea regarding the safety of a structure. Especially for structures being designed with a target index of reliability different from 3.8 (smaller or larger), for which there are no explicitly recommended 
partial factors in Eurocode, reliability analysis through simulations can be useful to compare the level of reliability with the target level.

\section{ACKNOWLEDGEMENTS}

The program of NATO: Seismic Upgrading of Bridges in South-East Europe by Innovative Technologies (Science for Peace SfP: 983828) is focused on fundamental research and development of innovative technology for seismic isolation and seismic protection of bridges. The support of NATO SfP is highly appreciated for the realization of this paper. Also, the authors would like to express the appreciation for Palisade Corporation for the availability and assistance with the software @Risk.

\section{LITERATURA REFERENCES}

[1] CEN, EN 1990, Eurocode - Basis of structural design, 2002

[2] CEN, EN 1991-2, Eurocode 1: Actions on structures - Part 2: Traffic loads on bridges, 2003

[3] CEN, EN 1998-2, Eurocode 8: Design of structures for earthquake resistance - Part 2: Bridges, 2005

[4] Croce P., Sanpaolesi L., Bridges - Actions and load combinations, Leonardo da Vinci Pilot Project - Development of Skills Facilitating Implementation of Eurocodes - Handbook 4 - Design of Bridges, 2005

[5] Gulvanessian H., Calgaro J.-A., Holický M., Designers' guide to EN 1990 Eurocode: Basis of structural design, Thomas Telford Publishing London, 2002

[6] Billinton R. and Allan R.N., Reliability Evaluation of Engineering Systems - Concepts and Techniques - Second Edition, Plenum Press New York and London, 1992

[7] Faber M. H., Risk and Safety in Civil Engineering Lecture notes, ETH Swiss Federal Institute of Technology Zurich, 2007

[8] Penelis G.G, Kappos A.J., Earthquake-Resistant Concrete Structures, Chapman \& Hall, 1997

[9] Sørensen J.D., Calibration of Partial Safety Factors in Danish Structural Codes, JCSS Workshop on Reliability Based Code Calibration, 2002

\section{REZIME}

\section{VREDNOVANJE KONSTRUKIJCKE POUZDANOSTI KORIŠĆENJEM METODA SIMULACIJE}

\section{Markel BABALLËKU \\ Brisid ISUFI}

\section{Brisid ISUFI}

Eurocode describes the "index of reliability" as a measure of structural reliability, related to the "probability of failure". This paper is focused on the assessment of this index for a reinforced concrete bridge pier. It is rare to explicitly use reliability concepts for design of structures, but the problems of structural engineering are better known through them. Some of the main methods for the estimation of the probability of failure are the exact analytical integration, numerical integration, approximate analytical methods and simulation methods. Monte Carlo Simulation is used in this paper, because it offers a very good tool for the estimation of probability in multivariate functions. Complicated probability and statistics problems are solved through computer aided simulations of a large number of tests. The procedures of structural reliability assessment for the bridge pier and the comparison with the partial factor method of the Eurocodes have been demonstrated in this paper.

Key words: structural reliability, index of reliability, probability of failure, Monte Carlo simulation, bridge pier
U Evrokodu 0 opisan je „indeks pouzdanosti“ kao mera konstrukcijske pouzdanosti, koja se odnosi na „verovatnoću otkaza“. U članku naglasak je na procenu pomenutog indeksa za armiranobetonski stub mosta. Nije uobičajeno eksplicitno korišćenje koncepta pouzdanosti u projektovanju konstrukcija, ali se problem konstrukcijskog inženjerstva bolje se razume preko nje. Neke od najvažnijih metoda za procenu verovatnoće otkaza su egzaktna analitička integracija, numerička integracija, aproksimativne analitičke metode $\mathrm{i}$ metode simulacije. U ovom radu je korišćena metoda Monte Karlo simulacije, jer nudi veoma dobar alat za procenu verovatnoće u multivarijante funkcija. Komlikovana verovatnoća i statistički problemi su rešeni pomoću Procedure procene konstrukcijske pouzdanosti supca most i upoređenje sa metodom parcijalnih faktora Evrokodova su ilustrovane u ovom radu.

Ključne reči: konstrukcijska pouzdanost, indeks pouzdanosti, verovatnoće otkaza, Monte Karlo simulacija, stubac mosta kompjutera koristeći simulacije velikog broja ispitivanja. 